\title{
Pengaruh Kesiapan Teknologi, Sumber Daya Manusia, Kerumitan, Keamanan Dan Kerahasiaan Terhadap Minat Dalam Menggunakan E-Filing
}

\author{
I Putu Oka Mahendra Putra ${ }^{1}$ \\ Fakultas Ekonomi dan Bisnis Universitas Udayana, Indonesia. \\ Email: okamahendra41@yahoo.co.id
}

\begin{abstract}
ABSTRAK
Penelitian ini bertujuan untuk mengetahui Pengaruh Kesiapan Teknologi, Sumber Daya Manusia, Kerumitan, Keamanan dan Kerahasiaan terhadap minat wajib pajak orang pribadi dalam menggunakan e-filing (Studi Kasus Pada KPP Badung Selatan). Penelitian ini dilaksanakan di KPP Pratama Badung Selatan. Jumlah populasi yang akan di teliti dalam penelitian ini tahun 2017 sejumlah 115.324 orang wajib pajak, sedangkan Jumlah sampel yang diambil sebanyak 100 orang wajib pajak, dengan metode nonprobability sampling dan teknik purposive sampling. Pengumpulan data dilakukan dengan penyebaran kuesioner. Metode analisis data menggunakan analisis regresi linier berganda. Berdasarkan hasil penelitian menunjukkan bahwa kesiapan teknologi, sumber daya manusia, keamanan dan kerahasiaan memiliki pengaruh positif terhadap minat wajib pajak orang pribadi didalam menggunakan $e-$ filing, sedangkan kerumitan berpengaruh negatif terhadap minat wajib pajak orang pribadi dalam menggunakan $e$-filing.
\end{abstract}

Kata Kunci : $\quad$ Teknologi; SDM; Kerumitan; Keamanan Dan Kerahasiaan; E-Filling.

\section{Effects of Technology Readiness, Human Resources, Complexity, Security and Confidentiality on Interest in Using E-Filing}

\begin{abstract}
This study aims to determine the Effect of Technology Readiness, Human Resources, Complexity, Security and Confidentiality on Individual Taxpayers in using e-filing (Case Study of Individual Taxpayers in South Badung KPP). This research was conducted at the KPP Pratama Selatan Badung. The population number that will be examined in this research in 2017 is 115,324 taxpayers, while the number of samples taken is 100 taxpayers, with the nonprobability sampling method and purposive sampling technique. Data collection is done by distributing questionnaires. The method of data analysis uses multiple linear regression analysis. Based on the results of the study show that the readiness of technology, human resources, security and confidentiality has a positive effect on the interest of individual taxpayers in using e-filing, while the complexity has a negative effect on the interest of individual taxpayers in using e-filing.
\end{abstract}

Keywords: $\quad$ Technology; HR; Complexity; Security And Confidentiality; E-Filing.

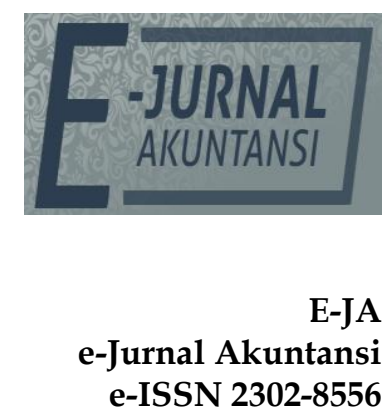

Vol.298 No. 1

Denpasar, Oktober

2019

Hal. 225-241

Artikel masuk:

27 Juni 2019

Tanggal diterima: 05 September 2019 


\section{PENDAHULUAN}

Sumber pendapatan dari sektor pajak merupakan peran yang sangatlah vital bagi berlangsungnya sistim pemerintahan pada sebuah negara, dikarenakan pendapatan paling besar sebuah negara yaitu memiliki sumber daripada pajak (Noviandini, 2012). Pendapatan pajak berasal daripada iuran yang diharuskan untuk terbayar oleh masyarakat sebagai konsekwensi diberlakukannya undang undang. Pendapatan negara yang memiliki sumber daripada sektor pajak tersebut akanlah dipakai bagi pembiayaan umum daripada seluruh kegiatan pemerintahan bahkan jadi satu dari sekian tolak ukur daripada berhasil atau tidaknya pada sektor perekonomian di sebuah Negara (Andreas, 2018). Hal tersebut jadi pemicu untuk Direktorat Jenderal Pajak didalam melaksanakan segala usaha bagi peningkatan pendapatan pajak daripada Wajib Pajak dengan melaksanakan pembaharuan-pembaharuan didalam sistim perpajakan. Sejumlah inovasi pembaharuan yang berkaitan dengan teknologi informasi didalam kegiatan perpajakan selalu dilaksanakan, dengan tujuan untuk membuat mudah dan mengoptimalkan proses layanan pada wajib pajak. Pembaharuan dalam sistem perpajakan ini ditandai dengan munculnya e-filing.

E-filing adalah suatu layanan pengiriman atau penyampaian SPT secara elektronik bagi wajib pajak orang pribadi maupun badan (perusahaan, organisasi) kepada Direktorat Jendral Pajak. Penggunaan sistem e-filing dapat dilakukan dimana saja dan kapan saja baik di dalam maupun di luar negeri, tidak tergantung pada jam kantor dan dapat juga dilakukan di hari libur (24 jam dalam 7 hari) dengan memanfaatkan jaringan koneksi internet secara online dan real time, sehingga wajib pajak tidak perlu lagi melakukan pencetakan semua formulir laporan dan menunggu tanda terima secara manual (Risal, 2013).

Penggunaan $e$-filing oleh Wajib Pajak Orang Pribadi di Provinsi Bali saat ini belum mencapai batas maksimal yang diinginkan (Wahyuningsih, Winaya, \& Yasintha, 2014). Berbagai kemudahan dan kelebihan yang ditawarkan oleh Direktorat Jenderal Pajak melalui sistem e-filling belum mampu meratakan pemakaian e-filing bagi Wajib Pajak (Wahyuningsih et al., 2014). Wajib pajak orang pribadi yang memberikan manfaat sistim e-filing hanyalaha sejumlah $53 \%$. Hal ini memperlihatkan masihlah banyaknya Wajib Pajak Orang Pribadi yang tidak memakai e-filing, faktor utama yang menyebabkan Wajib Pajak belum menggunakan $e$-filing adalah Wajib Pajak sebagian besar masih bingung untuk menyampaikan Surat Pemberitahuan Tahunannya melalui sistem $e$-filing (Hani \& Apriani, 2016).

Tabel 1. Penyampaian SPT Wajib Pajak Orang Pribadi Tahun 2015-2017

\begin{tabular}{ccc}
\hline Tahun & $\begin{array}{c}e-\text { filing } \\
\text { (WPOP) }\end{array}$ & $\begin{array}{c}\text { Manual } \\
\text { (WPOP) }\end{array}$ \\
\hline 2015 & 2.532 & 102.572 \\
2016 & 2.024 & 105.609 \\
2017 & 8.510 & 103.259 \\
\hline
\end{tabular}

Sumber: KPP Badung Selatan, 2018

Masalah minat juga terdapat di wilayah Badung Selatan. Berdasarkan data yang diperoleh peneliti dari KPP Badung Selatan menunjukkan minat Wajib Pajak orang pribadi dalam menggunakan e-filing di wilayah Badung Selatan masih 
rendah dibandingkan dengan penyampaian SPT secara manual (Subag Umum dan Kepatuhan internal KPP Badung Selatan, 2018). Minat Wajib Pajak Orang Pribadi dalam penyampaian SPT melalui e-filing atau secara manual dapat dilihat dari perbandingan penyampaian SPT Wajib Pajak Orang Pribadi Tahun 2015-2017 pada Tabel 1. Berdasarkan dari Tabel 1 penyampaian SPT Wajib Pajak Orang Pribadi dengan manual lebih tinggi dibandingkan dengan menyampaikan SPT dengan e-filing. Melewati selisih jumlah penyampaian SPT Wajib Pajak Orang Pribadi pada tabel diatas maka dapat ditarik kesimpulan rendahnya minat wajib pajak orang pribadi dalam memakai e-filing didalam penyampaian SPT. Rendahnya minat wajib pajak orang pribadi tersebut menyebabkan petugas pelayanan pajak sulit dalam mengelola SPT Masa ataupun SPT Tahunan dengan manual (Novrinda, 2014).

Berdasarkan sumber dari KPP Pratama Badung Selatan dapat diketahui bahwa ada beberapa kelemahan dari pengolahan SPT secara manual yaitu membutuhkan waktu yang lama dalam proses merekam lampiran SPT, tingginya akan risiko kemungkinan kesalahan yang terjadi pada saat perekaman data, dan perekaman SPT secara manual juga membutuhkan sumber daya manusia yang banyak, serta berpengaruh untuk memperlambat proses pelayanan pajak lainnya. Pemerintah khususnya Direktorat Jendral Pajak perlu menumbuhkan minat Wajib Pajak Orang Pribadi untuk menyampaikan SPT nya dengan menggunakan $e$-filing. Semakin banyaknya Wajib Pajak Orang Pribadi untuk menyampaikan SPT nya melalui e-filing akan memberikan beberapa manfaat diantaranya memudahkan para Wajib Pajak dalam penyampaian SPT tanpa harus mengantri di kantor Pelayanan Pajak sehingga dirasa lebih efektif dan efisien. Pelayanan pajak Orang Pribadi yang menggunakan e-filing pada Provinsi Bali ada 7 Kantor Pelayanan Pajak Pratama adalah Denpasar Barat, Denpasar Timur, Badung Selatan, Badung Utara, Tabanan, Gianyar, dan Singaraja. Ketujuh kantor pelayanan pajak itu sudah memakai sistim $e$-filing didalam menyampaikan Surat Pemberitahuannya. Tabel 2 menunjukkan data penyampaian SPT Wajib Pajak Orang Pribadi pada tahun 20152017.

Tabel 2. Penyampaian SPT melalui e-filing seluruh KPP di Kantor Wilayah Direktorat Jenderal Pajak Bali Tahun 2015-2017

\begin{tabular}{rlrcc}
\hline & KPP & \multicolumn{3}{c}{ Jumlah SPT lewat $e$-filling } \\
\hline 1. & KPP Denpasar Barat & 2015 & 2016 & 2017 \\
\hline 2. & KPP Denpasar Timur & 11.362 & 30.918 & 20.646 \\
3. & KPP Badung Selatan & 11.088 & 30.965 & 20.398 \\
4. & KPP Badung Utara & 8.039 & 17.430 & 12.065 \\
5. & KPP Tabanan & 8.594 & 20.645 & 12.605 \\
6. & KPP Gianyar & 9.330 & 37.213 & 17.099 \\
7. & KPP Singaraja & 9.186 & 48.900 & 25.238 \\
\hline
\end{tabular}

Sumber : Kanwil DJP Bali, 2018

Berdasarkan Data, penelitian ini dilakukan di KPP Pratama Badung Selatan karena jumlah data penyampaian SPT Tahunan Orang Pribadi melalui $e$-filing di KPP Pratama Badung Selatan adalah yang terendah, ini mengindikasikan bahwa minat Wajib Pajak Orang Pribadi di KPP Badung Selatan masih rendah. KPP Pratama Badung Selatan memiliki tugas serta fungsi yaitu melaksanakan 
pelayanan juga pengawasan perpajakan pada Kecamatan Kuta serta Kuta Selatan. Meningkatnya ataupun menurun pemakaian e-filing tersebut bisa dibentuk daripada sebuah tertarik dan tidaknya ataupun minat daripada wajib pajak dalam menggunakan $e$-filing untuk menyampaikan surat pemberitahuan (SPT). Berdasar kepada keadaan di KPP Pratama Badung Selatan itu, peneliti mempunyai anggapan butuhnya mengetahui factor-faktor apa sajalah yang bisa memberi pengaruh minat wajib pajak khusus orang pribadi didalam memakai $e$-filing.

Penelitian yang telah dilakukan oleh peneliti sebelumnya mengenai faktorfaktor yang memberikan pengaruh minat wajib pajak didalam pemakaian $e$-filing itu pula sempat dilaksanakan oleh, (Risal, 2013), (Sugiharti, 2015) serta (Wahyuningtyas, 2016) dari hasil penelitian memberikan petunjuk bahwasannya seluruh variable bebasnya memiliki pengaruh positif pada variable dependennya dimana hasil itu mempunyai perbedaan dengan penelitian (Desmayanti, 2012), bahwasannya kerumitan atau kompleksitas memiliki pengaruh negatif pada intensnya prilaku didalam memakai e-filing. Hasil penelitian sebelumnya yang tidaklah sama dengan penelitian (Tamara \& Arianto, 2014) yang memperoleh hasil bahwaannya keamanan dan kerahasiaan tidaklah memiliki pengaruh serta tidaklah memiliki pengaruh positif pada minat memakai $e$-filing. Berbedanya hasil penelitian tersebut yang menyebabkan peneliti menentukan agar memakai variable keamanan dan kerahasiaan. Menggunakan acuan penelitian (Desmayanti, 2012), (Tamara \& Arianto, 2014) serta (Wahyuningtyas, 2016), sehingga peneliti memiliki ketertarikan melakukan penelitian kembali mengenai hasil penelitian yang mempunyai perbedaan serta melaksanakan perkembangan penelitian pada variable-variable yang memiliki keterkaitan minat Wajib Pajak orang pribadi didalam menggunakan e-filing. Dari beberapa penelitian di atas, peneliti menambahkan sumber daya manusia sebagai variabel independen.

Berdasarkan uraian tersebut maka peneliti tertarik melakukan penelitian untuk menguji kembali faktor yang memiliki hasil tidak konsisten antara satu penelitian dengan penelitian lainnya. Judul penelitian yang peneliti rumuskan adalah "Pengaruh Kesiapan Teknologi, Sumber Daya Manusia, Kerumitan, Keamanan dan Kerahasiaan Terhadap Minat Wajib Pajak Orang Pribadi Dalam Menggunakan e-filing ( Studi Kasus Pada Kantor Pelayanan Pajak Badung Selatan)". Tujuan dari penelitian ini adalah untuk mengetahui dan menguji secara empiris pengaruh kesiapan teknologi, sumber daya manusia kerumitan serta keamanan dan kerahasiaan terhadap minat Wajib Pajak Orang Pribadi dalam menggunakan $e$-filing di KPP Pratama Badung Selatan.

Penelitian berikut akan dijelaskan mengenai pengaruh kesiapan teknologi, sumber daya manusia, kerumitan, keamanan dan kerahasiaan terhadap minat wajib pajak orang pribadi dalam menggunakan e-filing. Berdasar kepada uraian tersebut jadi Kerangka pemikiran teoritis penelitian ini disajikan pada Gambar 1 sebagai berikut:

Grand Theory :

TRA ( Theory Reasoned Action)

TAM ( Theory of Acceptance Model)

\section{Kajian Empiris}

1. Wibisono dan Toly (2014), Desmayanti (2012)

2. Ekamaulana (2016)

3. Rogers dan Shoemakers (1971), Desmayanti dan Zulaikha (2012), Muzdalifa (2016)

4. Wowor, dkk (2014), Wibisono dan Toly 
Sumber: Data Penelitian, 2018

\section{Gambar 1. Kerangka Konseptual}

Sesuai dengan Theory of Acceptance Model (TAM) yang memberi penjelasan bahwasannya seorang ingin memakai sebuah teknologi bisa terpengaruh dengan langsung ataupun tak langsung bagi persepsi pengguna untuk manfaat yang diberi sistim itu. Kesiapan teknologi memberikan pengaruh rasa ingin didalam memakai sistim informasi. Lalu dapat menimbulkan minat dalam memakai sistim informasi (e-filing) bila pada dasarnya pribadi individu memiliki ketersediaan menerima suatu teknologi baru didalam melaporkan pajak. Oleh karena hal tersebut bisa menjadi kesimpulan, apabila tingkat kesiapan teknologi tersebut meninggi jadi minat penggunaan makin tinggi pula. Peningkatan minat tersebut akanlah memberikan pengaruh intensnya pemakaian sistim informasi dengan berlanjut. Sistim e-filing tersebut sendiri pula haruslah telah memiliki tingkat kesiapan yang besar agar memberikan dukungan kelancaran didalam pembuatan laporannya. Sistim e-filing berikut jika tidaklah mempunyai kesiapan jadi akanlah bisa memberikan hambatan wajib pajak didalam melaporkan pajak, hingga kesiapan teknologi informasi bisa memberikan pengaruh minat wajib pajak dalam memakai e-filing.

Penelitian yang dilaksanakan oleh (Tamara \& Arianto, 2014) kesiapan teknologi informasi memberikan pengaruh minat wajib pajak didalam memakai e-filing di Surabaya. Hasil itu bila tingkat kesiapan teknologi informasi wajib pajak 
makin meninggi sehingga minat wajib pajak didalam menggunakan e-filing akanlah meninggi juga. (Desmayanti, 2012) memberikan bukti didalam penelitiannya bahwasannya kesiapan teknologi informasi wajib pajak memberikan pengaruh signifikan positif pada intensnya prilaku didalam pemakaian $e$-filing. Berdasar kepada uraian itu jadi didapatkan hipotesa seperti ini: $\mathrm{H}_{1}$ : Kesiapan Teknologi Berpengaruh Positif terhadap minat Wajib Pajak Orang Pribadi dalam menggunakan e-filing di KPP Pratama Badung Selatan.

Didalam teori Theory of Reasoned Action (TRA) yang menyatakan bahwasannya tentang gimana seseorang melakukan pertimbangan seluruh info yang tersedia dalam pembentukan minat ataupun rasa tertarik pada sesuatu. Kemudian jika sudah terbentuk minat maka sumber daya manusia atau dalam konteks ini adalah Wajib Pajak akan mau untuk mengikuti pelatihan agar dapat meningkatkan minat menggunakan e-filing. Sumber Daya Manusia terdiri dari daya pikir juga daya fisik di tiap-tiap individu. Atau lebih jelasnya adalah sebuah keahlian di tiap-tiap orang ditentukan dari daya pikir juga daya fisiknya. Sumber Daya Manusia jadi unsur yang sangatlah vital ddialam seluruh aktivitas yang dilaksanakan. Biarpun ada alat-alat yang canggih dengan tidak adanya Sumber Daya Manusia hal itu tak akan mempunyai arti apapun. Oleh dikarenakan Daya Pikir adalah modal mendasar yang dibawa dari lahir namun kemampuan didapat daripada usaha.

Penelitian dari (Handayani \& Tambun, 2016) memberikan penjelasan sebuah prilaku tak bisa terwujud bila keadaan objektif didalam lingkungan memberika halangan. Keadaan fasilitas pemakaian Sistem Informasi terdefinisi bagai "faktor-faktor objektif" yang bisa memudahkan melaksanakan sebuah tindakan. Faktor-faktor objektif itu diantaranya yaitu ketentuan-ketentuan yang memberi dukungan pemakai didalam memberi manfaat sistim informasi, misalkan pelatihan serta memberi bantuan pemakai saat mengalami kesusahan. Ekamaulana (2016) menyebut didalam risetnya bahwasannya SDM memberi pengaruh positif pada minat wajib pajak orang pribadi dalam memakai $e$-filing. Latihan dalam mengisi SPT memakai sistim e-filing memberi bantuan para pemakai e-filing memakai sistim itu. Berdasarkan uraian tersebut maka diperoleh hipotesis sebagai berikut:

$\mathrm{H}_{2}$ : Sumber Daya Manusia berpengaruh positif terhadap minat Wajib Pajak Orang Pribadi dalam menggunakan e-filing di KPP Pratama Badung Selatan.

Theory of Acceptance Model (TAM) memberi penjelasan bahwasannya agar memberikan peniaian penerimaan daripada sebuah teknologi yaitu daripada persepsi kemudahan agar digunakan. Persepsi kemudahan agar digunakan tersebut bisa terlihat saat sebuah teknologi gampang terpelajari, gampang terkuasai, gampang tergunakan serta gampang terpahami bagi pengguna. Berhubungan dengan teori tersebut yang melakukan penilaian penerimaan teknologi daripada persepsi kemudahan memakainya, saat teknologi (e-filing) terpandang oleh wajib pajak mempunyai kerumitan jadi hal itu membikin wajib pajak tak dapat mendapatkan teknologi (e-filing). Rasa rumit terdefinisi bagai pengharapan pemakai bahwasannya teknologi terbebas daripada usaha. Definisi kerumitan bagai tindakan persepsi pada teknologi komputer yang dijadikan persepsi bagai hal yang relative susah terpahami juga dipakai. 
Thomson menyatakan bahwasannya makin kompleksnya sebuah inovasi, makin rendah tingkat terserapnya (Thompson, Higgins, \& Howell, 2006). Kerumitan pula akanlah timbul, bila Wajib Pajak tidak mampu melakukan penerimaan suatu teknologi baru didalam pelaporan pajaknya (e-filling) dengan alasan tidak biasa melakukannya hingga Wajib Pajak memberikan interpretasi bahwasannya teknologi yang terbaru berikut mampu melakukan penyitaan waktu didalam melakukan pembelajaran ataupun sampai susah agar dilakukan pemahaman hingga Wajib Pajak malas dalam memakai $e$-filling. (Thompson et al., 2006) memberikan pernyataan bahwasannya makin komplek sebuah inovasi, jadi makin kecil tingkat penyerapan. Kerumitan akanlah timbul bila Wajib Pajak tidak mampu melakukan penerimaan suatu teknologi baru didalam melaporkan pajak (e-filing) dengan alasan tidak biasa serta dianggap bahwasannya teknologi yang baru tersebut bisa buang-buang waktu didalam melakukan pembelajaran sebuah yang baru tersebut ataupun bahkan susah agar terpahami, hingga Wajib Pajak malas dalam memakai e-filing. Didalam (Desmayanti, 2012) memberi pengungkapan, saat Wajib Pajak memberi persepsi bahwasannya $e$-filing tersebut rumit, jadi mereka akanlah memiliki kecendrungan agar tak memakai e-filling. Hal itu sejalan dengan hasil penelitian adalah bahwasannya kerumitan mempunyai pengaruh negatif pada intensnya prilaku didalam memakai e-filing. Menurut penelitian yang dilakukan oleh Muzdalifa (2016) dan (Ekamaulana \& Pusposari, 2016.), menyatakan bahwasannya persepsi kerumitan berpengaruh yang negatif pada intensnya prilaku didalam memakai e-filing. Sedangkan penelitian dari Wahyuningtyas, menyatakan bahwasannya persepsi kerumitan berpengaruh yang positif pada intensitas perilaku wajib pajak dalam menggunakan e-filing (Wahyuningtyas, 2016). Berdasarkan uraian tersebut maka diperoleh hipotesis sebagai berikut:

$\mathrm{H}_{3}$ : Kerumitan berpengaruh negatif terhadap minat Wajib Pajak Orang Pribadi dalam menggunakan e-filing di KPP Pratama Badung Selatan.

Teori TAM (Technology Acceptance Model) memiliki tujuan dalam membentuk dasar menelusuri pengaruh faktor eksternal pada kepercayaan, sikap serta tujuan penggunaan komputer. Bila kepercayaan Wajib Pajak akan tingkat keamanan dan kerahasiaan yang baik maka semakin meningkat minat wajib pajak dalam memakai e-filling. Keamanan memiliki arti bahwasannya pemakaian sistim informasi tersebut aman risiko hilang data ataupun info sangatlah rendah, serta risiko mencuri kecil. Kerahasiaan memiliki arti seluruh hal yang memiliki keterkaitan dengan info pribadi pemakai keterjaminan kerahasiaan tersebut, tidaklah ada orang yang memberitahu (Sugiharti, 2015). (Sugiharti, 2015) pula menyebut bahwasannya isu tentang keamanan serta kerahasiaan jadi isu yang paling dilihat oleh pemakai didalam pemakaian sistim informasi. Menurut Wowor, dkk (2014) memberi pernyataan bahwasannya didalam hal pemakaian $e$ filling, sebagian besar pemakai tak mengerti betul risiko keamanan serta kerahasiaan daripada e-filling. Hasil penelitian yang dilaksanakan Wowor, dkk (2014), memberi petunjuk bahwasannya keamanan serta kerahasiaan bisa memberikan pengaruh pada prilaku pemakaian e-filling. (Tamara \& Arianto, 2014) didalam penelitiannya membuktikan bahwa keamanan dan kerahasiaan mempengaruhi minat wajib pajak didalam memakai e-filing di Surabaya. 
Ekamaulana memberi pernyataan didalam penelitiannya keamanan dan kerahasiaan memiliki pengaruh positif pada minat wajib pajak orang pribadi dalam memakai e-filling (Ekamaulana \& Pusposari, 2016.). Hal tersebut karena keamanan serta kerahasiaan data pribadi tiap-tiap wajib pajak adalah hal yang vital dalam memberi keyakinan wajib pajak memakai $e$-filling. Berdasarkan uraian tersebut maka diperoleh hipotesis seperti berikut:

$\mathrm{H}_{4}$ : Keamanan dan Kerahasiaan berpengaruh positif terhadap minat Wajib Pajak Orang Pribadi dalam menggunakan e-filing di KPP Pratama Badung Selatan.

\section{METODE PENELITIAN}

Desain penelitian didalam penelitian berikut menggunakan metode kuantitatif. Jenis dan sumber data yang dipakai yaitu data primer yang berasal daripada kuesioner dan data sekunder yang asalnya dari Kantor Pelayanan Pajak Badung Selatan. Penelitan ini dilaksanakan di Kantor Pajak Pratama Badung Selatan Jl. Tantular No.4, Dangin Puri Klod, Denpasar Timur, Kota Denpasar, Bali 80234. Obyek penelitian adalah suatu sifat dari obyek yang ditetapkan oleh peneliti untuk dipelajari dan kemudian memperoleh kesimpulan (Sugiyono, 2013:38). Obyek dalam penelitian ini adalah pengaruh kesiapan teknologi, sumber daya manusia, kerumitan, kemanan dan kerahasiaan pada minat wajib pajak orang pribadi dalam memakai $e$-filling di KPP Badung Selatan.

Variable terikat $(\mathrm{Y})$ dalam penelitian berikut yaitu minat Wajib Pajak Orang Pribadi didalam menggunakan e-filling di KPP Badung Selatan. Variabel bebas dalam penelitian ini adalah $\mathrm{X}_{1}=$ Kesiapan Teknologi, $\mathrm{X}_{2}=$ Sumber Daya Manusia, $X_{3}=$ Kerumitan, $X_{4}$ Keamanan dan Kerahasiaan. Definisi operasional variable yaitu sebuah definisi yang memberi penjelasan pada seluruh variable bertujuan agar terhindar dari memberikan arti variable yang diteliti serta agar memberikan batasan masalah didalam penelitian, berikut akan dijelaskan definisi operasional tiap-tiap variable.

Desmayanti menyatakan bahwa, kesiapan teknologi dasarnya terpengaruh oleh individu itu sendiiri, apa didalam diri individu siap menggunakan teknologi mengkhusus didalam hal e-filling (Desmayanti, 2012). Kesiapan teknologi informasi pula memberikan pengaruh majunya pola berpikir individu berarti makin individu siap menerima teknologi yang terbaru memiliki arti makin majunya cara berpikir individu itu adalah mampu melakukan adaptasi dengan teknologi yang makin lama makin mengalami perkembangan. Dalam penelitian ini, mengukur kesiapan teknologi dapat digunakan indicator -indikator menurut (Desmayanti, 2012) SDM yang paham akan teknologi, adanya koneksi internet yang bagus dan adanya software dan hardware yang memadai. Indikator-indikator tersebut terukur dengan memakai skala ordinal dengan tehnik ukur skala Likert 4 Poin, dimana STS (sangat tidak setuju), TS (tidak setuju), S (setuju), dan SS (sangat setuju).

SDM mempunyai pengertian kemampuan terpadu yang memiliki asal daripada daya pikir juga daya fisik yang dimiliki tiap-tiap manusia yang melaksanakan juga sifat yang dilakukan masihlah memiliki hubungan yang erat contoh keturunan serta lingkungan, namun bagi prestasi kerja termotivasi oleh suatu rasa ingin didalam memberikan pemenuhan rasa inginnya. Dalam penelitian ini, mengukur sumber daya manusia dapat digunakan indicator - 
indikator menurut (Ekamaulana \& Pusposari, 2016) Sumber Daya Manusia yang ahli, Pelatihan memakai e-filling serta pengetahuan memakai sistim e-filling. Indikator-indikator tersebut terukur dengan memakai skala ordinal dengan tehnik ukur skala Likert 4 Poin, dimana STS (sangat tidak setuju), TS (tidak setuju), S (setuju), dan SS (sangat setuju).

Rogers serta Shoemaker didalam (Sadjiarto, 2013) memberikan definisi kerumitan bagai tingkat persepsi pada teknologi komputer yang dilakukan persepsi bagai sebuah hal yang relative susah terpahami serta dipakai. Suatu dinyatakan kompleks bila hal itu lebih dari terbatasnya kognitif seseorang. Berdasarkan pernyataan tersebut, bisa ditarik sebuah kesimpulan bahwasannya kerumitan memiliki pengaruh negative pada pemakaian sebuah sistim yang terbaru. Dalam penelitian ini, mengukur kerumitan dapat digunakan indicator indikator menurut Desmayanti (2012), Ekamaulana (2016): Waktu yang dibutuhkan dan Tingkat kesulitan. Indikator-indikator tersebut terukur dengan memakai skala ordinal menggunakan tehnik ukur skala Likert 4 Poin, dimana STS (sangat tidak setuju), TS (tidak setuju), S (setuju), dan SS (sangat setuju).

Sebuah sistim informasi bisa dibilang bagus apabila keamanan serta kerahasiaan sistim itu bisa diandalkan. Keamanan dan kerahasiaan pada sistim tersebut bisa terlihat lewat data pemakai yang aman dan rahasia tersimpan oleh sebuah sistim informasi (Desmayanti, 2012). Dalam penelitian berikut, mengukur keamanan dan kerahasiaan dapat digunakan indicator - indikator menurut (Tamara \& Arianto, 2014), (Ekamaulana \& Pusposari, 2016): Risiko pengguna terhadap hacker atau peretas data, Resiko data digunakan dengan salah oleh petugas pajak dan keahlian e-filling didalam melakukan antisipasi masalah yang berkaitan dengan data. Indikator-indikator tersebut terukur dengan memakai skala ordinal dengan tehnik ukur skala Likert 4 Poin, dimana STS (sangat tidak setuju), TS (tidak setuju), S (setuju), dan SS (sangat setuju).

Minat merupakan sebuah fungsi jiwa agar mampu menuju sebuah yang adalah kekuatan dalam serta nampak diluar bagai gerak-gerik. Minat mampu terdefinisi bagai tertariknya seorang pada sebuah obyek ataupun kegiatan yang murni dari dalam diri sendiri. Dalam penelitian ini, mengukur minat wajib pajak dapat digunakan indikator-indikator menurut (Tamara \& Arianto, 2014), (Ekamaulana \& Pusposari, 2016): Minat untuk mempelajari, Minat untuk terus menggunakan e-filing dan Merekomendasikan kepada pihak lain. Indikatorindikator tersebut terukur dengan memakai skala ordinal dengan tehnik ukur skala Likert 4 Poin, dimana STS (sangat tidak setuju), TS (tidak setuju), S (setuju), dan SS (sangat setuju).

Populasi didalam riset berikut yaitu wajib pajak orang pribadi yang efektive tercatat pada KPP Badung Selatan tahun 2017 adalah 475.948 orang. Sampel pada penelitian akan dipilih sedemikian rupa sehingga dapat mewakili sifat-sifat populasi. Jumlah sampel ditentukan dengan rumus Slovin berikut:

$$
\mathrm{n}=\frac{\mathrm{N}}{1+\mathrm{N \alpha}^{2}}
$$

Berdasarkan data yang diperoleh dari KPP Badung Selatan, diketahui besaran populasi Wajib Pajak orang pribadi yang tercatat per 31 Desember 2017 sebanyak 41.337 Dengan memakai rumus slovin, maka jumlah sample riset berikut yaitu 100 sampel. Metode penentuan sample pada riset berikut non probability 
sampling dengan teknik purposive sampling. Purposive sampling adalah teknik penentuan sampel dengan pertimbangan tertentu. Pertimbangan tertentu dalam memilih sampel pada penelitian ini adalah responden yang diminta untuk mengisi kuesioner harus memenuhi kriteria yaitu: Responden berstatus efektif tercatat Kantor Pelayanan Pajak Pratama Badung Selatan dan Responden harus memiliki nomer NPWP.

Teknik analisis data yang digunakan dalam penelitian ini adalah Analisis Statistik Deskriptif dan Analisis Regresi Linier Berganda yang sebelumnya akan dilakukan Uji Asumsi Klasik serta Pengujian Instrumen Penelitian terlebih dahulu. Analisis regresi linier berganda dipakai agar tahu ataupun mendapat gambaran tentang pengaruh variable bebas di variable terikat serta mempunyai tujuan agar melakukan estimasi serta melakukan prediksi rata-rata populasi ataupun nilai rata-rata variable terikat berdasar nilai variable bebas yang didapat (Ghozali, 2016:93). Model regresi linier berganda ini dirmuskan seperti ini :

$$
Y=\alpha \beta_{1} X_{1}+\beta_{2} X_{2}+\beta_{3} X_{3}+\beta_{4} X_{4} e
$$

\section{HASIL DAN PEMBAHASAN}

Data dalam penelitian ini diperoleh dari kuesioner yang telah disebarkan kepada responden sejumlah 100 wajib pajak orang pribadi yang terdaftar di KPP Pratama Badung Selatan. Karakteristik responden meliputi, jenis kelamin, umur, dan pekerjaan yang tercatat di Kantor Pelayanan Pajak Pratama Badung Selatan. Jenis kelamin digunakan untuk mengetahui jumlah responden laki-laki dan perempuan. Responden laki-laki berjumlah 40 orang (40 persen), sedangkan responden perempuan berjumlah 60 orang (60 persen). Umur digunakan untuk mengetahui jumlah umur responden di KPP Pratama Badung Selatan. Responden berusia 21-30 tahun berjumlah 22 orang (22 persen), responden berusia 31-40 tahun berjumlah 29 orang (29 persen), responden berusia $41-50$ tahun berjumlah 38 orang (38 persen), dan responden berusia diatas 50 tahun berjumlah 11 orang (11 persen). Jenis pekerjaan dipakai untuk mengetahui jumlah pekerjaan responden. Responden yang pekerjaannya pegawai berjumlah 63 orang (63 persen), dan pengusaha 37 orang (37 persen). Jenis wajib pajak digunakan untuk memenuhi kriteria dalam penelitian ini, dimana wajib pajak orang pribadi yang digunakan. Responden wajib pajak orang pribadi berjumlah 100 orang (100 persen). Responden yang tercatat di Kantor Pelayanan Pajak Pratama Badung Selatan merupakan kriteria yang diperlukan didalam penelitian ini. Responden yang terdaftar di KPP Pratama Badung Selatan berjumlah 100 orang (100 persen).

Tabel 3. Hasil Uji Validitas

\begin{tabular}{cccc} 
Variabel & Instrumen & Pearson Correlation & Keterangan \\
& & & \\
\hline Kesiapan Teknologi & X.1.1 & 0,730 & Valid \\
(X1) & X.1.2 & 0,854 & Valid \\
& X.1.3 & 0,570 & Valid \\
Sumber Daya Manusia & X.2.1 & 0,647 & Valid \\
(X2) & X.2.2 & 0,873 & Valid
\end{tabular}




$\begin{array}{cccc}\text { Kerumitan } & \text { X.2.3 } & 0,841 & \text { Valid } \\ \text { (X3) } & \text { X.3.1 } & 0,923 & \text { Valid } \\ \text { Keamanan dan } & \text { X.3.2 } & 0,934 & \text { Valid } \\ \begin{array}{c}\text { Kerahasiaan } \\ \text { (X4) }\end{array} & \text { X.4.1 } & 0,934 & \text { Valid } \\ & \text { X.4.2 } & 0,907 & \text { Valid } \\ \text { filling } & \text { X.4.3 } & 0,792 & \text { Valid } \\ \text { (Y) } & \text { Y.1 } & 0,912 & \text { Valid } \\ & \text { Y.2 } & 0,871 & \text { Valid } \\ \text { Y. } & \text { Y.3 } & 0,864 & \text { Valid }\end{array}$

Sumber: Data Penelitian, 2018

Sebuah intrumen didalam riset dinyatakan valid bila bisa melakukan pengukuran apa yang diinginkan untuk terukur. Sebuah intrumen dinyatakan valid bila mempunyai koefisien korelasi diantara butir dengan skor total didalam intrumen itu melebihi daripada 0,30 dengan tingkat kesalahan Alpha 0,05. Hasil pengujian valid tidaknya intrumen penelitian tersaji di Tabel 3 yang memberi petunjuk bahwasannya semua indikasi didalam Kesiapan Teknologi, Sumber Daya Manusia, Kerumitan, Keamanan serta Kerahasiaan pada Minat Wajib Pajak Orang Pribadi dalam memakai e-filling memiliki nilai Pearson Correlation yang melebihi angka 0,30 hingga semua indikasi itu dinyatakan sudah lolos persyaratan validitas data.

Uji Reliabilitas merupakan pengujian yang digunakan untuk memenuhi ketepatan jawaban kuesioner pada satu periode dengan periode lainnya. Suatu instrumen dikatakan reliable jika koefisien cronbach's alpha $\geq 0,70$. Hasil pengujian reliabilitas disajikan pada Tabel 4 sebagai berikut:

\section{Tabel 4. Hasil Uji Reliabilitas}

\begin{tabular}{ccc}
\hline Variabel & Cronbach's Alpha & Keterangan \\
\hline Kesiapan Teknologi & 0,780 & Reliabel \\
Sumber Daya Manusia & 0,822 & Reliabel \\
Kerumitan & 0,907 & Reliabel \\
Keamanan dan & 0,856 & Reliabel \\
$\quad$ Kerahasiaan & 0,857 & Reliabel \\
\hline Minat Penggunaan $e$-filing
\end{tabular}

Sumber: Data Penelitian, 2018

Hasil pengujian reliabilitas intrumen pada riset ini tersaji di Tabel 4 yang memberi petunjuk bahwasannya tiga intrumen riset adalah Kesiapan Teknologi, Sumber Daya Manusia, Kerumitan, Keamanan dan Kerahasiaan dan Minat Penggunaan $e$-filing memiliki koefisien cronbach's alpha yang lebih besar dari angka 0,60 sehingga pernyataan pada kuesioner dapat dikatakan reliabel.

Statistik deskriptive didalam riset berikut dipakai agar memberi info tentang karakter variable-variable riset, diantaranya nilai minimum, maksimum, 
rata-rata, simpangan baku dengan $\mathrm{N}$ merupakan jumlah responden penelitian. Hasil statistika deskriptive tersaji di Tabel 5 sebagai berikut.

Tabel 5. Hasil Statistik Deskriptif

\begin{tabular}{lrrrrr}
\hline & $\begin{array}{c}\text { Kesiapan } \\
\text { Teknologi }\end{array}$ & $\begin{array}{c}\text { Sumber Daya } \\
\text { Manusia }\end{array}$ & Kerumitan & $\begin{array}{c}\text { Keamanan dan } \\
\text { Kerahasiaan }\end{array}$ & $\begin{array}{c}\text { Minat e- } \\
\text { filling }\end{array}$ \\
\hline Mean & 8,4000 & 8,7400 & 5,3100 & 8,7600 & 8,6300 \\
Std. & 1,80348 & 2,19098 & 1,74480 & 2,12308 & 2,37689 \\
Deviation & & & & & 4,507 \\
Variance & 3,253 & 4,800 & 3,044 & 4,00 & 5,650 \\
Minimum & 6,00 & 4,00 & 2,00 & 12,00 & 12,00 \\
Maximum & 12,00 & 12,00 & 8,00 & &
\end{tabular}

Sumber: Data Penelitian, 2018

Penjabaran dari hasil uji statistik deskriptif pada Tabel 5 adalah sebagai berikut: Variabel kesiapan teknologi mempunyai nilai minimum sejumlah 6,00 dan nilai maksimum sejumlah 12,00. Nilai rata-rata dari variable kesiapan teknologi yaitu 8,4000 dengan standar deviasi sebesar 1,80348, Variabel sumber daya manusia mempunyai nilai minimum sejumlah 4,00 dan nilai maksimum sejumlah 12,00 . Nilai rata-rata dari variable sumber daya manusia yaitu 8,7400 dengan standar deviasi sebesar 2,19098, Variabel kerumitan memiliki nilai minimum sebesar 2,00 dan nilai maksimum sebesar 8,00 . Nilai rata-rata dari variabel sumber daya manusia adalah 5,3100 dengan standar deviasi sebesar 1,74480, Variabel keamanan dan kerahasiaan memiliki nilai minimum sebesar 4,00 dan nilai maksimum sebesar 12,00. Nilai rata-rata dari variabel sumber daya manusia adalah 8,7600 dengan standar deviasi sebesar 2,12308, Variable minat wajib pajak orang pribadi didalam menggunakan e-filling mempunyai nilai minimum sebanyak 4,00 dan nilai maksimum sebanyak 12,00 . Nilai rata-rata dari variable sumber daya manusia yaitu 8,6300 dengan standar deviasi sebesar 2,37689 .

Model regresi dinyatakan model yang bagus bila model itu terbebas daripada asumsi klasik statistika. Sebuah model dengan teoritis akanlah memberikan hasil nilai parameter penduga yang cocok apabila lolos syarat asumsi klasik regresi, meliputi uji normalitas, multikolineritas, serta heteroskedastisitas. Uji normalitas bertujuan untuk menguji apakah dalam model regresi, variabel penggangu atau residual mempunyai distribusi normal atau tidak. Untuk menghindari terjadinya bias, data yang digunakan harus berdistribusi dengan normal. Model regresi yang baik adalah memiliki data normal atau mendekati normal. Pengujian residual menggunakan uji Kolmogorov-Smirnov. Residual berdistribusi normal apabila tingkat signifikasinya menunjukkan nilai lebih besar 0,05 .

Tabel 6. Hasil Uji Normalitas

\begin{tabular}{cc}
\hline & Unstandardized Residual \\
\hline $\mathrm{N}$ & 100 \\
Kolmogorov-Smirnov Z & 0,083 \\
Asymp.Sig.(2-tailed) & 0,083 \\
\hline
\end{tabular}

Sumber: Data Penelitian, 2018

Berdasar kepada Tabel 6 bisa terlihat bahwasannya nilai Kolmogorov Sminarnov (K-S) sejumlah 0,083, namun nilai Asymp. Sig. (2-tailed) sejumlah 0,083. Hasil itu memberikan indikasi bahwasannya model persamaan regresi itu sudah memiliki distribusi normal dikarenakan nilai Asymp. Sig. (2-tailed) 0,083 lebih 
tinggi daripada nilai alpha 0,05. Uji multikolinearitas dilaksanakan agar terlihat apa ada hubungan yang sempurna diantara variable independen yang dipakai di riset. Uji dilaksanakan lewat, nilai tolerance serta nilai VIF (Variance Inflation Factor) pula. Apabila nilai tolerance lebih daripada $10 \%$ ataupun VIF kurang daripada 10, jadi dikatakan tidak ada multikolinearitas.

\section{Tabel 7. Hasil Uji Multikolinearitas}

\begin{tabular}{lcc}
\hline \multicolumn{1}{c}{ Variabel } & Tolerance & VIF \\
\hline Kesiapan Teknologi (X1) & 0,776 & 1,289 \\
Sumber Daya Manusia (X2) & 0,677 & 1,478 \\
Kerumitan (X3) & 0,737 & 1,357 \\
Keamanan dan Kerahasiaan $(X 4)$ & 0,765 & 1,307 \\
\hline
\end{tabular}
Sumber: Data Penelitian, 2018

Berdasarkan Tabel 7 dapat dilihat bahwa nilai tolerance dan VIF dari variabel Kesiapan teknologi, sumber daya manusia, kerumitan dan keamanan dan kerahasiaan menunjukkan nilai tolerance lebih besar dari 10\% dan nilai VIF lebih kecil dari 10 yang berarti model persamaan regresi bebas dari multikolinearitas. Dalam penelitian ini untuk mendeteksi heteroskedastisitas data dapat dilakukan dengan cara Uji Glejser. Glejser mengusulkan untuk meregresi nilai absolut residual terhadap variabel independen.

Tabel 8. Hasil Uji Heteroskedastisitas

\begin{tabular}{lrr}
\hline & \multicolumn{1}{c}{ T } & \multicolumn{1}{c}{ Sig. } \\
\hline (Constant) & 2,797 &, 006 \\
Kesiapan Teknologi (X1) &, 066 &, 947 \\
Sumber Daya Manusia (X2) & 1,308 &, 194 \\
Kerumitan (X3) & $-1,300$ &, 197 \\
Keamanan dan Kerahasiaan (X4) &, 627 &, 532 \\
\hline
\end{tabular}

Sumber: Data Penelitian, 2018

Berdasar kepada Tabel 8 dbisa terlihat bahwasannya nilai Sig. daripada variable Kesiapan Teknologi sebesar 0,947, variabel Sumber Daya Manusia sebesar 0,194, variabel Kerumitan sebesar 0,197 dan variabel Keamanan dan Kerahasiaan sebesar 0,532. Hasil tersebut menunjukkan bahwa seluruh variabel terbebas dari masalah heteroskedastisitas karena nilai Sig. $>0,05$.

Tabel 9. Hasil Analisis Regresi Berganda

\begin{tabular}{lrrr}
\hline \multicolumn{1}{c}{ Variabel } & $\begin{array}{c}\text { Nilai Koefisien } \\
\text { Regresi }\end{array}$ & $\begin{array}{c}\mathrm{t} \\
\text { hitung }\end{array}$ & Nilai Signifikansi \\
\hline Konstanta & & 1,433 &, 015 \\
Kesiapan Teknologi (X1) &, 108 & 1,121 &, 025 \\
Sumber Daya Manusia (X2) &, 317 & 3,077 &, 003 \\
Kerumitan (X3) &,- 025 &,- 249 &, 038 \\
Keamanan dan Kerahasiaan &, 265 & 2,735 &, 007 \\
(X4) & & & 0,862 \\
R & & & 0,716 \\
R Square & & &
\end{tabular}


Sumber: Data Penelitian, 2018

Berdasar kepada hasil analisis regresi linier berganda seperti yang tersaji di Tabel 9, jadi didapat nilai koefisien regresi untuk masing-masing variabel adalah 0,108 untuk variabel Kesiapan Teknologi (X1), 0,317 untuk variabel Sumber Daya Manusia (X2), -0,025 untuk variabel Kerumitan (X3) dan 0,265 untuk variabel Keamanan dan Kerahasiaan (X4), sehingga dapat dituliskan model persamaan regresinya sebagai berikut:

$$
\mathrm{Y}=0,108 \mathrm{X}_{1}+0,317 \mathrm{X}_{2}-0,025 \mathrm{X}_{3}+0,265 \mathrm{X}_{4}
$$

Nilai 0,108 adalah nilai koefisien regresi bagi variable Kesiapan Teknologi yang artinya Kesiapan Teknologi mempunyai pengaruh positif pada Minat Penggunaan $e$-filing jadi bila Kesiapan Teknologi naik satu satuan jadi nilai Minat Penggunaan e-filling akan naik juga sejumlah 0,108. Nilai 0,317 adalah nilai koefisien regresi untuk variabel Sumber Daya Manusia yang artinya Sumber Daya Manusia memiliki pengaruh positif pada Minat Penggunaan e-filling jadi bila SDM naik satu satuan jadi nilai Minat Penggunaan $e$-filling juga akanlah naik sejumlah 0,317 . Nilai $-0,025$ adalah nilai koefisien regresi untuk variabel Kerumitan yang artinya Kerumitan memiliki pengaruh negatif terhadap Minat Penggunaan $e$-filing jadi bila Kerumitan naik satu satuan maka nilai Minat Penggunaan e-filling akanlah turun sebanyak 0,025. Nilai 0,265 adalah nilai koefisien regresi untuk variable Keamanan dan Kerahasiaan yang mempunyai arti Keamanan dan Kerahasiaan memiliki pengaruh positif pada Minat Penggunaan $e$-filling jadi bila Keamanan serta Kerahasiaan naik satu satuan jadi nilai Minat Penggunaan $e$-filling pula akanlah naik sejumlah 0,265.

Koefisien determinasi menilai berapa jauhnya pengaruh model didalam memberikan penerangan bervariasinya variable terikat. Nilai koefisien determinasi yaitu diantara nol sampai satu. Nilai $\mathrm{R}^{2}$ yang rendah mempunyai arti pengaruh variable-variable bebas didalam memberikan penjelasan variasi variable terikat amatlah terbatas. Nilai yang hamper menyentuh satu mempunyai arti variable-variable bebas memberi hampir memberi seluruh info yang diperlukan agar melakukan prediksi bervariasinya variable terikat. Berdasar kepada hasil analisis regresi linier berganda sama dengan yang tersaji di Tabel 9 didapat nilai determinasi total sejumlah 0,687 memiliki pengertian bahwasannya sejumlah 68,7 persen variasi Minat Penggunaan $e$-filling dipengaruhi oleh variasi Kesiapan teknologi, sumber daya manusia, kerumitan dan keamanan dan kerahasiaan sedangkan sisanya sebesar 31,3 persen dijelaskan oleh faktor lain yang tidak dimasukkan ke dalam model.

Sig. Tabel 9 hasil uji $\mathrm{f}$ (ANOVA) memberi petunjuk besar tidaknya angka probabilitas ataupun signifikansi di penghitungan ANOVA. Besaran yang tercantum dipakai dalam pengujian kelayakan Model Analisis (sejumlah variable $\mathrm{x}$ memberikan pengaruh variable $\mathrm{y}$ ) dengan syarat angka probability yang bagus agar dipakai bagai model regresi haruslah $<0,05$. Nilai tersebut dapat terlihat di kolom Sig. Apabila signifikansi < 0,05, jadi Model Analisa dapat kita anggap layak. Jika nilai signifikansi $\geq 0,05$, maka Model Analisis dianggap tidak layak. Karena F signifikasi sama dengan 0,000 $<0,005$ maka $\mathrm{H}_{0}$ ditolak dan $\mathrm{H}_{1}$ diterima. Artinya ada pengaruh secara simultan dari variabel Kesiapan teknologi, sumber daya 
manusia, kerumitan dan keamanan dan kerahasiaan terhadap Minat Penggunaan e-filing.

Berdasar kepada Tabel 9, dijabarkannya dari hasil uji hipotesis (uji t) penelitian ini adalah sebagai berikut: Karena $\mathrm{t}$ sig Pengaruh Kesiapan Teknologi pada Minat Penggunaan e-filling sama dengan 0, $025<0,05$ maka $\mathrm{H}_{0}$ ditolak dan $\mathrm{H}_{1}$ diterima. Artinya ada pengaruh yang signifikan secara parsial Kesiapan Teknologi Terhadap Minat Penggunaan e-filing. Sedangkan nilai koefisien regresi variable Kesiapan Teknologi adalah sejumlah 0,108 ini berarti variable Kesiapan Teknologi memiliki pengaruh yang positif dan signifikan pada Minat Penggunaan e-filling. Pengaruh Sumber Daya Manusia Terhadap Minat Penggunaan e-filling memiliki $\mathrm{t}$ sig sama dengan $0,003<0,05$ jadi $\mathrm{H}_{0}$ ditolak serta $\mathrm{H}_{1}$ diterima. Hal ini berarti ada pengaruh yang signifikan secara parsial diantara Sumber Daya Manusia pada Minat Penggunaan e-filling. Sedangkan nilai koefisien regresi variabel Sumber Daya Manusia adalah sebesar 0,317 ini artinya variabel Sumber Daya Manusia mempunyai pengaruh yang positif dan signifikan pada Minat Penggunaan $e$-filling.

Pengaruh Kerumitan pada Minat Penggunaan e-filing memiliki t sig sama dengan $0,038<0,05$ jadi $\mathrm{H}_{0}$ ditolak serta $\mathrm{H}_{1}$ diterima. Hal tersebut berarti adanya pengaruh yang signifikan secara parsial diantara Kerumitan pada Minat Penggunaan e-filling. Sedangkan nilai koefisien regresi variabel Sumber Daya Manusia adalah sebesar -0,025 ini artinya variabel Kerumitan mempunyai pengaruh yang negatif dan signifikan pada Minat Penggunaan $e$-filling. Pengaruh Keamanan dan Kerahasiaan pada Minat Penggunaan e-filing memiliki $\mathrm{t}$ sig sama dengan 0,007 <0,05 jadi $\mathrm{H}_{0}$ ditolak dan $\mathrm{H}_{1}$ diterima. Ini berarti ada pengaruh yang signifikan secara parsial diantara Keamanan dan Kerahasiaan pada Minat Penggunaan e-filling. Sedangkan nilai koefisien regresi variabel Sumber Daya Manusia adalah sebesar 0,265 ini artinya variabel Keamanan dan Kerahasiaan memiliki pengaruh yang positif dan signifikan terhadap Minat Penggunaan $e^{-}$ filling.

\section{SIMPULAN}

Berdasar hasil dan pembahasan, simpulan ini dapat diuraikan sebagai berikut. Kesiapan Teknologi memiliki pengaruh positif pada minat wajib pajak orang pribadi disalam menggunakan e-filling di Kantor Pelayanan Pajak Pratama Badung Selatan. Artinya, semakin tinggi kesiapan teknologi, jadi makin tinggi pula minat wajib pajak orang pribadi didalam menggunakan e-filing, Sumber daya manusia memiliki pengaruh positif pada minat wajib pajak orang pribadi didalam menggunakan e-filling di Kantor Pelayanan Pajak Pratama Badung Selatan. Artinya, makin baik sumber daya manusia, maka akan memberikan peningkatan minat wajib pajak orang pribadi didalam menggunakan e-filling, Kerumitan memiliki pengaruh negatif pada minat wajib pajak orang pribadi didalam menggunakan e-filling di Kantor Pelayanan Pajak Pratama Badung Selatan. Artinya, makin rumit penggunaan e-filing tersebut, maka wajib pajak orang pribadi akan tidak berminat dalam menggunakan e-filing, Keamanan dan Kerahasiaan berpengaruh positif terhadap minat wajib pajak orang pribadi dalam menggunakan e-filing di Kantor Pelayanan Pajak Pratama Badung Selatan. Artinya, semakin bagus tingkat keamanan dan kerahasiaan terhadap penggunaan 
e-filling, maka minat wajib pajak orang pribadi dalam menggunakan efiling akan meningkat.

Berdasarkan kesimpulan tersebut di atas, maka peneliti dapat memberikan beberapa saran sebagai berikut. Saran yang bisa diberikan bagi peneliti selanjutnya bisa menggunakan lokasi penelitian lain dan memperluas wilayah pengambilan sampel untuk mengetahui minat wajib pajak orang pribadi maupun wajib pajak badan dalam menggunakan e-filing di wilayah atau ruang lingkup yang berbeda. Peneliti berikutnya juga bisa memberi penambahan variable lain. Hal ini bertujuan supaya hasil dari penelitian berikutnya dapat digunakan secara lebih luas, Saran bagi masyarakat dalam hal ini sebagai wajib pajak yaitu dapat lebih aktif dalam menggali informasi mengenai perpajakan karena saat ini sudah ada kemudahan berupa teknologi informasi sehingga diharapkan mampu untuk meningkatkan kesadaran sebagai wajib pajak agar lebih patuh dalam hal pelaporan SPT. Pemerintah dalam hal ini Direktorat Jendral Pajak DJP mampu memberikan peningkatan kualitas pelayanan didalam memngenalkan e-fil;ing, baik didalam media cetak ataupun media elektronik.

\section{REFERENSI}

Andreas, M. (2018). Pengaruh E-FILING Pada Tingkat Kepatuhan Wajib Pajak dalam Melapor SPT Tahunan Orang Pribadi di Kantor Pelayanan Pajak Pratama Lubuk Pakam.

Desmayanti, E. (2012). Faktor-Faktor yang Mempengaruhi Penggunaan Fasilitas E-Filling oleh Wajib Pajak sebagai Sarana Penyampaian SPT Masa Secara Online dan Realtime. Diponegoro Journal of Accounting, 1(1), 1-12.

Ekamaulana, F. A., \& Pusposari, D. (2016). Analisis Faktor-Faktor Yang Mempengaruhi Minat Wajib Pajak Orang Pribadi Dalam Menggunakan E-Filing (Studi Empiris Pada Wajib Pajak Orang Pribadi Di Kota Banjarmasin). (4), 1-21.

Handayani, K. R., \& Tambun, S. (2016). Pengaruh penerapan sistem e-filing dan pengetahuan perpajakan terhadap kepatuhan wajib pajak dengan sosialisasi sebagai variabel moderating (Survei pada Perkantoran Sunrise Garden di Wilayah Kedoya, Jakarta Barat). Media Akuntansi Perpajakan, 1(2), 59-73. Retrieved from www.journal.uta45jakarta.co.id

Hani, S., \& Apriani, F. (2016). Faktor - faktor yang mempengaruhi perilaku wajib pajak orang pribadi terhadap penggunaan e-filing. Jurnal Akuntansi, Keuangan $\mathcal{E}$ Perpajakan Indonesia, 03(01), 83-97.

Noviandini, N. C. (2012). Pengaruh Persepsi Kebermanfaatan, Persepsi Kemudahan Penggunaan, Dan Kepuasan Wajib Pajak Terhadap Penggunaan E-Filing Bagi Wajib Pajak Di Yogyakarta. I, 15-22.

Novrinda, I. (2014). Pengaruh Persepsi Wajib Pajak Orang Pribadi Terhadap Penggunaan Electronic Filing (E-Filing) Di Kpp Pratama Palembang Ilir BaraT.

Risal, L. (2013). Pengaruh Perilaku Wajib Pajak Terhadap Penggunaan E-Filing Wajib Pajak Di Kota Manado. 1(3), 44-51.

Sadjiarto, I. L. dan A. (2013). Wajib Pajak Untuk Menggunakan E-Filing. Tax $\mathcal{E}$ Accounting Review, 3(2), 1-15.

Sugiharti, M. A. (2015). Analisis Efektivitas Dan Kelayakan Sistem Pelaporan Pajak Menggunakan E- Filing Terhadap Kepuasan Wajib Pajak. 6(2), 54-67. 
Tamara, L., \& Arianto, A. (2014). Analisis Faktor-Faktor Yang Mempengaruhi Minat Wajib Pajak Dalam Penggunaan E-Filing Di Surabaya. Jurnal Perpajakan, 4(1), 1-15.

Thompson, R. L., Higgins, C. A., \& Howell, J. M. (2006). Personal Computing: Toward a Conceptual Model of Utilization. MIS Quarterly, 15(1), 125. https://doi.org/10.2307/249443

Wahyuningsih, E., Winaya, I. K., \& Yasintha, P. N. (2014). Meningkatkan Kepatuhan Wajib Pajak Orang Pribadi ( Studi Kasus Kantor Pelayanan Pajak Pratama Badung Selatan ). 1-10.

Wahyuningtyas, S. (2016). Faktor-Faktor Yang Mempengaruhi Intensitas Perilaku Wajib Pajak Dalam Menggunakan E-FILING ( Studi Empiris Pada Wajib Pajak Orang Pribadi di Kota Surakarta ). 